\title{
Border Searches and the Fourth Amendment
}

Customs officials conducting border searches have always been exempt from the usual fourth amendment requirement that searches be based on probable cause. Although the courts have experienced diffculty in determining when searches not undertaken at the border itself should qualify as border searches, they have universally assumed that the reasonableness and constitutionality of such searches never depend upon the existence of probable cause. Unfortunately, none of the arguments advanced justifies this treatment of border searches. Although several factors may differentiate border from normal searches, they do not warrant exempting all border searches from the requirement of probable cause. Sound, intelligent border search decisions require consideration of the extent to which a border crossing raises the probability that evidence will be obtained or justifies a relaxation of the traditional requirement of probable cause for a search within the country. Since the Supreme Court has already recognized the principles that would be relevant for such an analysis, border searches can and should be integrated into normal fourth amendment law.

\section{The Border Search Exemption}

Since the first border search statute was enacted in 1789,1 customs officials have been authorized to stop and examine any vehicle, person, or baggage arriving in the United States on suspicion that merchandise is concealed which is subject to duty or which cannot legally be imported into the United States.2 Similar legislation empowers customs officers to search any vehicle or vessel anywhere in the United States

1. Act of July 31, 1789, ch. 5, I Stat. 29, 43 (1789).

2. 19 U.S.C. \& 482 (1964) provides:

Any of the officers or persons authorized to board or search vesscls may stop, search, and examine, as well without as within their respective districts, any rehicle, beast, or person, on which or whom he or they shall suspect there is merchandise which is subject to duty, or shall have been introduced into the United States in any manner contrary to law, whether by the person in possession or charge, or by, in or upon such vehicle or beast, or othertvise, ...

Under 19 U.S.C. $\$ 1582$ (1964):

The Secretary of the Treasury may prescribe regulations for the scarch of persons and baggage and he is authorized to employ female inspectors for the examination and search of persons of their orm sex; and all persons coming into the United States from foreign countries shall be liable to detention and search by authorized officers or agents of the Government under such regulations.

See 19 C.F.R. § 23.1(d) (1967). 
for contraband, ${ }^{3}$ and immigration officials are authorized to conduct searches for illegally entered aliens within a reasonable distance from the border (currently defined as 100 miles) without probable cause. ${ }^{4}$ The constitutionality of such provisions has never been questioned by the courts. Regardless of their intrusiveness, all searches designated "border searches" have automatically been exempt from requirements of probable cause.

Recent circuit court cases involving intrusive or body cavity searches and searches far removed from the border have confirmed and perhaps even broadened this border search exception. Although the courts have obviously been troubled by the notable absence of any satisfying rationale for the exception, they have attempted to obscure these difficulties by reasoning that such searches are adequately controlled by the general fourth amendment requirement of "reasonableness." Unfortunately, however, the courts have failed to delineate the determinants of reasonableness by standards which reflect the need for and dangers of border searches.

Thus, in Rivas $v$. United States ${ }^{5}$ and Henderson $v$. United States ${ }^{0}$ the Ninth Circuit attempted unsuccessfully to respond to the appellants' contention that Schmerber $v$. California ${ }^{7}$ should be applied to intrusive searches of the person at the border. In Schmerber the Supreme Court had held that even where probable cause for an arrest for drunken driving existed, an intrusive search incident to the arrestblood testing, there-was lawful only if there was a "clear indication" that relevant evidence would be found. Although the opinion seems to suggest that such a "clear indication" is an additional requirement to be piled atop the need for probable cause for arrest before "the interests in human dignity and privacy which the Fourth Amendment

3. 19 U.S.C. \& 1581(a) (1964) provides:

(a) Any officer of the customs may at any time go on board of any vessel or velicle at any place in the United States ... or at any other authorized place, without as well as within his district, and examine the manifest and other documents and papers, and examine, inspect, and search the vessel or vehicle and every part thercof and any person, trunk, package, or cargo on board, and to this end may hail and stop such vessel or vehicle, and use all necessary force to compel compliance.

4. Under 8 U.S.C. \& 1357(a) (1964):

Any officer or employee of the Service authorized under Regulations prescribed by the Attorney General shall have power without warrant-

(3) within a reasonable distance from any external boundary of the United States, to board and search for aliens any vessel within the territorial waters of the United States and any railway car, aircraft, conveyance, or vehicle. . . .

"Reasonable distance" is defined by 8 C.F.R. \& 287.1 (1967) as 100 air miles from any external boundary, or any shorter distance fixed by the district director.

5. 368 F.2d 703 (9th Cir. 1966), cert. denied, 386 U.S. 945 (1967).

6. F.2d $\rightarrow 1$ CRIM. L. REP. 2275 (9th Cir. 1967).

7. 386 U.S. 757 (1966). 
protects"8 can be overriden by an intrusive search, the Ninth Circuit concluded that Schmerber could be reconciled with its exemption of intrusive border searches from the requirement of probable cause. Ignoring the relationship in Schmerber of the "clear indication" test to the requirement for probable cause for arrest, the circuit court asserted that such an indication was required under the rubric of rensonableness that it had previously applied in intrusive border search cases. ${ }^{9}$ While the appellant apparently offered Schmerber as part of a frontal attack on the border search exception, the court chose simply to engraft that decision onto the traditional exception. Thus, the court seems to have assumed that a crossing of the border served as a triggering event for application of a "clear indication" test in the same way that an arrest upon probable cause triggered the test in Schmerber. Since there was no underlying finding of any probable cause in the border search context, however, the court by "applying" Schmerber simply placed a putatively libertarian gloss on the border search doctrine while changing its substance little if at all..$^{10}$

The courts' recent attempts to delineate the characteristics of extended border searches have been no more satisfactory. According to the Ninth Circuit in Alexander $v$. United States, 11 whether a search not undertaken at the border is exempt from the probable cause requirement as an "extended border search" depends on

whether the totality of the surrounding circumstances, including the time and distance elapsed as well as the manner and extent of surveillance, are such as to convince the fact finder of a reasonable certainty that any contraband which might be found in or on the

8. Id. at $769-70$.

9. Rivas v. United States, 368 F.2d at 710-12.

10. The "clear indication" test is stated in Rizas as follows:

An honest "plain indication" that a search involving an intrusion bejond the body's surface is justified cannot rest on the mere chance that desired eridence may be obtained. Thus we need not hold the search of any body cavity is justified merely because it is a border search, and nothing more. There must csist facts creating a clear indication, or plain suggestion of the smuggling. Nor need these facts reach the dignity of nor be the equivalent of "probable cause" necessary for an arrest and search at a place other than the border.

368 F.2d at 710 (emphasis added).

Compare this formulation with that in Schmerber, 384 U.S. at 769-70.

The Rivas rule is not appreciably different from the pre-Schmerber ases in the Fifth and Ninth Circuits which approve intrusive personal searches at the border so long as they are "reasonable." Blefare v. United States, 362 F.2d 870 (9th Cir. 1960); Lane v. United States, 321 F.2d 573 (5th Cir. 1963), cert. denied, 381 U.S. 920 (1965); Bartera v. United States, 276 F.2d 654 (5th Cir. 1960); King v. United States, 258 F.2d 754 (5th Cir. 1958), cert. denied, 359 U.S. 939 (1959); Blackford v. United Stztes, 247 F 2d 745 (9th Cir. 1957), cert. denied, 356 U.S. 914 (1958). See Note, Search and Seizure at the BorderThe Border Search, 21 RuTGERs L. REv. 513 (1967); Comment, Intrusite Border SearchesIs Judicial Control Desirable? 115 U. PA. L. REv. 276 (1966).

11. 362 F.2d 379 (9th Cir. 1966), cert. denied, 385 U.S. 977 (1960). 
vehicle at the time of search was aboard the vehicle at the time of entry into the jurisdiction of the United States. ${ }^{12}$

The rationale for this test is that "the primordial purpose of a search by Customs officers is not to apprehend persons, but to seize contraband property unlawfully imported ...." If that were in fact the purpose, the time and place of the search would be immaterial provided that the government proved that the contraband seized had in fact crossed the border, as the test requires. But that is not in practice the purpose of such extended searches. The appellants in both Alexander and Rodriguez-Gonzales v. United States, ${ }^{14}$ another recent case with analogous facts, had not crossed the border with the contraband; but by delaying the search of the car involved in each case, the government managed to sweep them in along with the contraband. Had the government wanted only to seize the contraband, there is no reason suggested in either case why it could not have done so at the border. The use of the fact that the car had crossed the border as a continuing excuse for a search thus allowed the government to invade the personal privacy of the appellants without probable cause. And since they had not crossed the border with the contraband, the test advanced by the court is illogical when advanced to justify not the seizure of the contraband but rather its use as evidence against the appellants. ${ }^{16}$

\footnotetext{
12. Id. at 382.

13. Id.

14. 378 F.2d 256 (9th Cir. 1967)

15. Searches of border crossers in the immediate vicinity of the border have uni. versally been affirmed as border searches. Thomas v. United States, $372 \mathrm{~F} .2 \mathrm{~d} 252$ (bth Cir. 1967); Valadez v. United States, 358 F.2d 721 (5th Cir. 1966); Taylor v. United States, 352 F.2d 329 (9th Cir. 1965); Mansfield v. United States, 308 F.2d 221 (5th Cir. 1962); Murgia v. United States, 285 F.2d 14 (9th Cir. 1960).

Searches farther removed from the border have also been sustained as border searches. These searches are typically preceded by surveillance, and the searches werc not con. ducted at the authorized border station either because the suspect had not been identificd until after he had cleared customs or because the authorities hoped to apprchend his accomplices inside this country. Morales y. United States, 378 F.2d 187 (Gth Cir. 1967); Lannon v, United States, 381 F.2d 858 (9th Cir. 1967); Rodriguez-Gonzales v. United States, 378 F.2d 256 (9th Cir. 1967); Alexander v. United States, 362 F.2d 379 (9th Cir, 1966); Rodriguez v. United States, 292 F.2d 709 (4th Cir, 1961), aff'g, 195 F. Supp. 13 (\$.D. TCX. 1960).

A related set of cases deals with immigration officers (usually doubling as customs officers) who, in stopping vehicles within 100 miles of the border to search for illegal aliens pursuant to \& U.S.C. \& 1357 (1964) uncover narcotics. Those scarches which uncover narcotics incidentally during proper questioning about citizenship are affirmed on the theory that the officer who spots narcotics while performing his other duties need not blind himself to the crime being committed in his presence. But the im. migration officers may not conduct a search aimed at revealing narcotics without probible cause. Renteria-Medina v. United States, 346 F.2d 853 (9th Cir. 1965); Fernandez v. United States, 321 F.2d 283 (9th Cir. 1963); Contreras v. United States, 291 F.2d 63 (9th Cir. 1961) (illegal search); United States v. Hortze, 179 F. Supp. 913 (S.D. Calif. 1959) (illegal search); Haerr v. United Statęs, 240 F.2d 533 (5th Cir, 1957),

In some sense Alexander actually expands the pawer of customs officials to conduct
} 
II. The Alleged Justifications for the Border Search Exception

\section{A. The Argument From History}

The original customs statute exempting border searches from probable cause requirements was passed by the First Congress, which also proposed the Bill of Rights. ${ }^{16}$ It has often been argued that this fact demonstrates the validity of the present border search exemption. ${ }^{17}$ However, this fact is not dispositive for three reasons. First, the legislators may have passed the customs statute of 1789 without considering fully the applicability to border searches of the moral position to which they were about to commit the community in drafting the fourth amendment. Second, the community's standards of reasonableness may have changed over time. And third, changes in the underlying facts may have made unreasonable a search which would have been reasonable by the same standards in 1789 .

The Supreme Court has already recognized the nonconclusiveness of the argument from history in fourth amendment cases as in other areas. In Camara v. Municipal Court ${ }^{\mathbf{1 8}}$ the Court ignored the argument from history on which it had itself relied eight years before in Frank 0. Maryland. ${ }^{19}$ In overruling Frank by forbidding punishment of individuals for refusing to admit warrantless housing inspectors, the Court undermined the argument frequently advanced for refusing on historical grounds to inquire into the justification for the border search exception.

\section{B. Policy Interests at the Border}

It has also been argued that the border search exception is justified by the vital national interest in preventing illegal entry and smuggling, particularly of narcotics. ${ }^{20}$ Although special conditions prevail-

extended border searches. Prior Ninth Gircuit cases which rejected the gorernment's theory of an extended border search seem to turn on the lack of surveillance from the time of the border crossing. Contreras v. United States, 291 F.2d 63 (9th Cir. 1961); Plazola v. United States, 291 F.2d 56 (9th Cir. 1961). Alexander's emphasis on surveillance seems consistent with these cases. However, although the Fifth Circuit has always granted customs officers great latitude in conducting extended border searches, it has recognized that there is some geographical point, however vaguely defined, bejond which "normal" probable cause takes over and the extraordinary border search pover ceaces. See Thomas v. United States, 372 F.2d 252, 254 (5th Cir. 1967) (dictum), citing Carroll v. United States, 267 U.S. 132 (1924).

16. Act of July 31, 1789, ch. 5, 1 Stat. 29, 43 (1789). See Barnett, A Report on Search and Seizure at the Border, AM. CRns. L.Q. Aug. 1963, at 36 (customs problems).

17. Boyd v. United States, 116 U.S. 616, 623 (1886).

18. 387 U.S. 523 (1967); see See v. Seattle, 387 U.S. 541 (1967).

19. 359 U.S. $360(1959)$.

20. While smuggling has always been a problem at the border, it has become more acute since the enactment of the federal prohibitions on the importation of narcoties and 
ing at the border are unquestionably relevant for determining what kinds of searches are reasonable, such special factors do not by themselves justify the current border search exception. The Supreme Court recognized in $\operatorname{Ker} \boldsymbol{v}$. California ${ }^{21}$ that special problems of enforcement should be given weight in determining the reasonableness of a search, but such considerations do not justify a blanket exemption from probable cause requirements that fails to weigh the competing interests that the fourth amendment protects. ${ }^{22}$

\section{An Alternative to the Border Search Exception}

\section{A. Weights in the Balance}

The fourth amendment was designed to balance the state's interests in enforcing its laws against the individual's interest in his dignity and privacy. Although for various reasons almost all border searches do affect these interests in a peculiar fashion, several types of border searches can be clearly differentiated.

As a class, border searches can be distinguished from normal searches of individuals pursuant to criminal investigations on three grounds. First, since an individual crossing a border belongs to a class whose members frequently violate certain laws in the process of entering, the fact of his crossing is by itself some evidence that he may be violating some law. Second, since the individual crossing a border is on notice that certain types of searches are likely to be made, his privacy is arguably less invaded by those searches. Third, since non-intrusive personal searches at the border are administered to a class (international travelers) which is not deemed unworthy, such searches lack the quality of insult felt by an individual singled out for a search.

Clearly, however, not all border searches are homogeneous in these

marijuana. See, e.g., 21 U.S.C. \$\$ 173-74 (1964) (narcotics) and 21 U.S.C. § 176(a) (1964) (marijuana).

Narcotics are easily obtainable in Mexico, and the Mexican-American border is the scene of a large volume of illicit trade in narcotics. Mexico is convenient to large numbers of American addicts and pushers, and the incentive for them to smuggle is evidently sufficient for them to be willing to risk customs inspections at the border. Becausc of their small size, narcotics are uniquely suited to concealment in body cavitics, and this practice is common at the border. In Blackford the Federal Government asserted that between 18 and 20 per cent of the international narcotics traffic in that area is conducted by smuggling the drugs in body cavities. $247 \mathrm{~F} .2 \mathrm{~d}$ at 752. The court in Rivas also noted the practice. 368 F.2d at 709 .

21. 374 U.S. 23, 33-34 (1963).

22. Camara is relevant in this regard. In that case, while the Supreme Court recognized the importance of the administrative search in the maintenance of minimal stanclards of housing and health, nevertheless, these factors did not bar the Court from requiring a warrant procedure in order to give due weight to the rights of privacy and freedom from unreasonable search. 387 U.S. at 535-39. 
respects. Thus, although individuals are likely to expect non-intrusive searches of their baggage and perhaps their outer clothing at the border, they will not be prepared for intrusive personal searches or extended border searches. Since such searches also tend to separate the parties searched from the morally neutral class of international travelers, they will be more insulting as well as more invasive of privacy. Intrusive personal searches are particularly suspect in this regard: in addition to singling out and surprising the person, such searches by their very nature insult and affront the dignity of any member of our society.

The connection between border crossings and the probability that an offense is being committed also depends on the type of search undertaken. Although a substantial percentage of border crossers may conceal illicit or dutiable merchandise in their baggage, vehicles, or clothing, a much smaller proportion hides such materials in their body cavities. Indeed, unless there is a tip from an informer, evidence of current or recent drug use, or perhaps a criminal record of smuggling or addiction, there is almost no reason to suspect that an individual crossing the border is concealing materials in this manner.

In short, although there is justification for treating border searches as a special class, such searches differ significantly among themselves. Such distinctions must be recognized if border searches are to be regulated in an intelligent manner. Although the fourth amendment does not itself distinguish among types of searches, the Supreme Court has recognized almost all the relevant distinctions in its recent fourth amendment opinions. Thus, in Camara the Court (l) decided that membership in a suspect class may contribute to probable cause; (2) concluded that because searches of morally neutral classes are less insulting to the individual searched, such searches may be undertaken with a lower probability that they will reveal relevant evidence; and (3) in guaranteeing the individual the right to a warrant recognized (though perhaps insufficiently) the protection that notice affords the individual's right to privacy. ${ }^{23}$ In Schmerber ${ }^{24}$ (and potentially in the stop and frisk cases), ${ }^{25}$ the Court concluded that the intrusiveness of a

23. 387 U.S. 523 (1967). But in Camara, unlike the border search, it should be noted that the search was itself morally neutral and was not aimed at revealing criminal violations.

24. 384 U.S. 757 (1966).

25. See, e.g., People v. Peters, 18 N.Y.2d 238, 219 N.E.2d 595, 273 N.Y.S.2d 217 (1965),

prob. juris. noted, 386 U.S. 980 (1967). The New York Court of Appenls majority expressed the idea behind the New York "stop and frisk" law, N.Y. CODE Cruss. P. \& 180-a (Mckinney Supp. 1967):

The attempt to apply a single standard of probable cause to all interferences-i.e., 
search bears on its reasonableness. And in $K e r^{26}$ the majority opinion acknowledged that state authorities may properly take their special enforcement problems into consideration in evolving reasonable stan. dards for searches and seizures. Thus, by applying Camara, Schmerbor, and $\mathrm{Ker}$, the courts could articulate standards distinguishing the special features of the several yarieties of border searches without departing from normal fourth amendment principles.

\section{B. Some Applications}

As we have seen, several special features should affect the courts' evaluation of normal or extended searches; (1) the government's interest in preventing the entrance of illegal aliens and merchandise; (2) the importance of the illicit international narcotics trade; (3) the probability of smuggling attempts at the border; (4) the difficulty of detecting narcotics smuggling; (5) the effect of notice on the extent to which the individual's privacy is invaded; (6) the fact that inclividuals searched because of their membership in a morally neutral class have less cause to feel insulted; and (7) the peculiar offensiveness of intrusive personal searches.

Four types of searches will be examined in light of these factors: (1) examination of identification papers; (2) searches of baggage, vehicle, and clothing; (3) intrusive personal searches; and (4) extended border sẹarches,

\section{Examination of Identification Papers}

$X$ attempts to cross from Mexico into California. A customs agent asks to examine his identification papers and proof of American citizenship. This is not an unreasonable search because the very fact that $X$ is coming from a foreign country puts his identification and citizenship at issue. At this level, $X$ 's interests in privacy are minimal--the examination is routine, expected, and noninsulting. Hence, the border crossing itself makes it reasonable to question $X$ about his citizenship. ${ }^{27}$

to treat a stop as an arrest and a frisk as a search-produces a standard cither so strict that reasonable and necessary police work becomes unlawful or so diluted that the individual is not adequately protected. The varying standards now in effect ... , best resolye this problem.

18 N.Y.2d at 247,219 N.E.2d at 600,273 N.Y.S.2d at 224.

Prior to $\$ 180-a$, New York courts developed judicially a similar set of distinctions. Sce, e.g., People v. Rivers, 14 N.Y.2d 441, 201 N.E.2d 32, 252 N.Y.S.2d 458 (1964), cert, denied, 379 U.S, 978 (1965), California courts have developed a similar approach. Sce, e.g., Pcople v. Dumas, 251 A.C.A. 699, 59 Cal. Rptr. 541 (1967).

26. 374 U.S. 23, 33-34 (1963).

27. Witt v. United States, 287 F.2d 389, 391 (9th Gir.), cert. denied, 366 U.S. 950 (1961), offers this argument as a rationale for all border searches: 


\section{Searches of Baggage, Vehicle, and Clothing}

The customs officer then asks $X$ if he has anything to declare. On $X$ 's negative reply, the officer proceeds to examine closely $X$ 's baggage, automobile and outer clothing, including pockets. Clearly, these actions constitute a search, and $X$ 's interests in privacy have been invaded even if the search is conducted in a reasonable manner with only minimal disarrangement of $X$ 's possessions. Yet, since $X$ is on notice that such a search may be undertaken, this invasion of his privacy may be less serious. Moreover, since $X$ is being searched as a result of his membership in a morally neutral class, the investigation should not be considered insulting. On the other hand, the state's interest in searching people like $X$ is substantial. No alternative enforcement methods are available and $X$ does belong to a group whose members frequently do violate the laws. Such searches should therefore be upheld. It would probably be preferable to rationalize this species of search in terms of its reasonableness, although it might also be possible to articulate the standard applied by reference to a sort of group probable cause analogous to the concept of area probable cause created in Camara. ${ }^{28}$

\section{Intrusive Personal Searches}

In both the above situations, the individual interests at stake were sufficiently small to justify relaxing normal probable cause requirements. Such a result is not warranted where intrusive personal searches are concerned. Intrusive personal searches are no less offensive at the border. Such searches are unusual, and the border crosser has no reason to expect such an intense examination of his person. The fact that such searches occur at the border does not affect their inherent ten-

No question of whether there is probable cause for a search exists when the search is incidental to the crossing of an international border, for there is reason and probable cause to search every person entering the United States from a foreign country, by reason of such entry alone.

But carrying the presumption to include all border searches is of doubtrul validity since most border crossers do not violate the law. The later Ninth Circuit cases (e.g., Rivios and Henderson) do not claim that the fact of crossing the border provides probable cause but that it makes probable cause unnecessary.

28. The argument for retaining a limited border search exception for lower levels of search confined to authorized border stations and for not emplojing the group probable cause approach suggested by Camara is that Camara dealt with administrative searches for housing code violations which, unlike the border search, seldom involve criminal sanctions. To accept the Camara approach for even such a limited area as low-level border searches may have an undesirable impact on our requirement of particularized probable cause for searches involving criminal sanctions. It would probablv be wiser to accept frankly the necessity of a limited border search exception than to open up probable cause to further dilutions in other areas of criminal law where the probability is high that offenders will be found in a given group. 
dency to degrade. And no less than elsewhere, an intrusive search cven at the border insults the victim by singling him out for special treatment as a morally suspect person. Accordingly, intrusive border searches should not be exempt from normal requirements of probable cause. Indeed, as Schmerber suggests, although in a different context, intrusive personal searches may well require more than probable cause. In short, although the fact that $X$ is crossing the border may contribute to a probability that he is hiding illicit matter in his body cavities, that fact alone neither amounts to probable cause nor justifies a relaxation of that standard.

To begin to sort out the additional facts that might justify a finding of probable cause, several more hypothetical situations are needed.

(a) Assume that $X$ has identified himself and that the results of a search of baggage, vehicle, and clothing were negative. Would the customs officer be justified in demanding that $X$ strip down for a body inspection without having any other information? The function of the body search is to reveal special kinds of contraband that are small and easily concealed on the body-e.g., narcotics or gem stones. The probability that a particular individual is attempting to smuggle such items is certainly far lower than that normally required for a finding of probable cause. Such a search should therefore not be permitted, as it is now under the misconceived "clear indication" test presently employed by the Ninth Circuit.

(b) Assume the same set of facts, except that the search of $X$ 's luggage revealed some item which is subject to duty. While X's attempt to evade the customs laws shows some propensity to violate the law, the attempt alone does not justify the conclusion that he is likely to attempt to import contraband of the kind concealed on the body. An intrusive personal search for narcotics or gem stones is still unreasonable on these facts alone; there is not probable cause to believe that the search will reveal illicit materials.

(c) Assume the same set of facts, except that the search of baggage did reveal narcotics. $X$ is subject to arrest, since possession or importation of narcotics is an offense. ${ }^{29}$ Since narcotics are preeminently the sort of contraband concealed in body cavities, an incidental body search might then be justified. One relevant factor would be the amount of narcotics discovered in the person's vehicle or baggage. If a large shipment has been discovered, it is unlikely that the person has gone to the trouble to conceal a small additional amount in a body

29. See note 20 supra. 
cavity. If, on the other hand, only a scattered trace of narcotics is discovered in, say, baggage, this might indicate that the principal shipment was removed and is hidden in or on his body.

(d) Assume the same set of facts, except that the baggage search revealed a "narcotics kit" without narcotics, or that $X$ is observed by a qualified expert to be under the influence of narcotics, or that $X$ is seen to have fresh needle marks on his arms, characteristically caused by injections of narcotics. These facts, the border situation, and the availability of narcotics in Mexico would seem to create the requisite probable cause for a body search.

(e) Assume that $X$ has registered at the border as a narcotics addict or violator..$^{30}$ While Beck $v$. Ohio ${ }^{31}$ holds that past conviction for a crime does not by itself allow a finding of probable cause, such information may properly be taken into account.

(f) Assume that $X$ has never been convicted of a narcotics offense and has not registered as an addict, and that the baggage search revealed nothing incriminating. But also assume that $X$ has been named by an informant as having narcotics in his possession. If the informant has been "reliable" in the past, if $X$ has been specifically named, and the tip includes some of the underlying circumstances (e.g., the reliable informant saw $X$ make narcotics purchase in Mexico and gives details of the transaction), this fact coupled with the crossing of a border where narcotics smuggling is common could amount to probable cause for the body search. ${ }^{32}$ If $X$ has not been specifically named, but only described, $X$ might still be searched where the available information (e.g., license number, detailed physical description, expected time and place and time of border crossing) is sufficient to identify $\mathrm{X}$ as the person described by the tip.

Where the informant cannot be shown to have been "reliable," his tip should be radically downgraded as a factor contributing to probable cause. Inside the country, the word of an unaccredited informant, unsupported by other information, would not justify a search; border crossers are not sufficiently suspect to justify different treatment. ${ }^{33}$

30. An addict or convicted offender is required to register at the border on entering and leaving the United States under 18 U.S.C. § 1407 (1964).

31. 379 U.S. 89 (1964).

32. See id.; Draper v. United States, 358 U.S. 307 (1959).

33. The other border factors deemed important still hold in this situation, so a tip from an unaccredited informer arguably should not always be disregarded. It depends on the nature of the tip, its specificity, the reasons the officers may have to believe it, short of accreditation and corroborative or suspicious behavior at the border. To say that an unaccredited tip should alway's be disregarded is to discount the importance of the special circumstances prevailing at the border, which Congress certainly has not done, 


\section{Extended Border Searches}

$X$ has cleared customs and has entered the United States. At this point the normal requirements of probable cause should be enforced for a search of his vehicle unless the government can show an adequate reason for not conducting the search at the border. $X$ will no longer be prepared for a search and a search will no longer seem directed to him as a member of the morally neutral group of border crossers. Fis interests will be as adversely affected by an extended border search as by a nomborder search. The fact that $X$ has just crossed a border might still be relevant in determining the existence of probable cause to search him or his vehicle since it would increase the probability that contraband might be found. However, this effect would be vitiated to the extent that (1) $X$ had been searched at the border itself, (2) he had not been kept under constant surveillance, or (3) time and distance had elapsed. Similarly, if $X$ has surrendered his vehicle to $Y$-as was the case in Rodriguez-Gonzales ${ }^{34}$ - the fact that the vehicle has recently entered the country should not alone justify its search; the border crossing is merely a factor contributing to probable cause.

\section{Conclusion}

The border search exception to the fourth amendment should be reexamined. Although border searches are differentiable as a class, they are not internally homogeneous. The fact that an individual has recently crossed a border does increase the probability that illicit miterials will be found, but at least where intrusive and extended border searches are concetned, the government should not be exempt from normal requirements of probable cause.

and which a court should be reluctant to do absent a showing that these factors arc indeed not as important as Congress evidently believes.

34. Rodriguez-Gonzales v. United States, 378 F.2d 256 (9th Cir. 1967). 